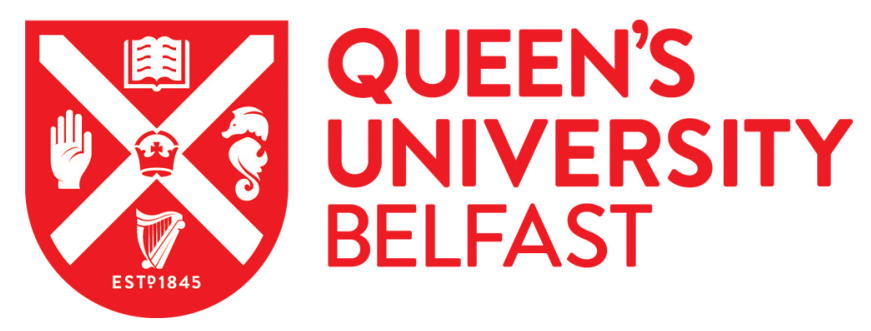

\title{
Interventions to improve medicines management for people with dementia: a systematic review
}

McGrattan, M., Ryan, C., Barry, H. E., \& Hughes, C. M. (2017). Interventions to improve medicines management for people with dementia: a systematic review. Drugs \& Aging, 34(12), 907-916. https://doi.org/10.1007/s40266017-0505-3

\section{Published in:}

Drugs \& Aging

\section{Document Version:}

Peer reviewed version

Queen's University Belfast - Research Portal:

Link to publication record in Queen's University Belfast Research Portal

\section{Publisher rights}

(c) 2017 Springer International Publishing AG, part of Springer Nature.

This work is made available online in accordance with the publisher's javascript:void(0);policies. Please refer to any applicable terms of use of the publisher.

\section{General rights}

Copyright for the publications made accessible via the Queen's University Belfast Research Portal is retained by the author(s) and / or other copyright owners and it is a condition of accessing these publications that users recognise and abide by the legal requirements associated with these rights.

Take down policy

The Research Portal is Queen's institutional repository that provides access to Queen's research output. Every effort has been made to ensure that content in the Research Portal does not infringe any person's rights, or applicable UK laws. If you discover content in the Research Portal that you believe breaches copyright or violates any law, please contact openaccess@qub.ac.uk. 
Interventions to improve medicines management for people with dementia: a systematic review

\section{Running title}

Interventions to improve medicines management for people with dementia

\section{Authors}

Mairead McGrattan a , Cristín Ryan ${ }^{\mathrm{b}}$, Heather E. Barry ${ }^{\mathrm{a}}$, Carmel M. Hughes ${ }^{\mathrm{a}^{*}}$

\section{Affiliations}

aschool of Pharmacy, Queen's University Belfast, 97 Lisburn Road, Belfast, BT9 7BL, Northern Ireland, UK

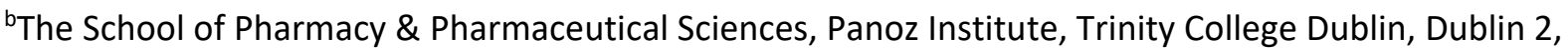
Ireland

\section{*Corresponding author}

Professor Carmel M. Hughes

Primary Care Research Group, School of Pharmacy, Queen's University Belfast, Medical Biology Centre, 97 Lisburn Road, Belfast, BT9 7BL, Northern Ireland, UK

T: +44 (0)289097 2147

F: +44 (0)289024 7794

E: c.hughes@qub.ac.uk 


\section{Abstract}

Background The importance of optimising medicines management for people with dementia has been emphasised through research and policy. However, evidence is currently lacking regarding how to achieve this in this patient population.

Objective To assess the effectiveness of medicines management interventions for people with dementia, living in their own home or a care home, with or without nursing care.

Methods A systematic literature search was conducted in February 2016 across six electronic databases and three trial registries. Inclusion criteria were randomised controlled trials of medicines management (prescribing, dispensing, adherence, and/or review) interventions for people with dementia living in their own homes or care homes, with or without nursing. An assessment of quality was conducted for all studies, using the Cochrane tool for assessing the risk of bias. All outcomes were considered using a narrative approach.

Results Overall, 1,365 articles were identified, with three studies eligible for inclusion ( $n=475$ participants). The studies were heterogeneous both in terms of intervention components, setting and outcomes used. Aspects of medicines management targeted included medication review, adherence and administration. Improvements in psychotropic prescribing were observed, however the interventions had limited effects on other outcomes such as well-being, falls and dementia severity.

Conclusion This review highlights the limited number of studies examining medicines management interventions for people with dementia. Of the work that has been conducted to date, emphasis has been placed on psychotropic drug use. Future research must target community-dwelling dementia patients and take a holistic approach to medicines management.

\section{Key points}

- People with dementia are commonly prescribed complex medication regimens which can be difficult to manage.

- Interventions to date have focused on reducing psychotropic drug use.

- There is a need for more well-designed interventions taking a holistic approach to medicines management for people with dementia. 


\section{Background}

Dementia has been described by the World Health Organisation as a public health priority [1]. As the population ages, the number of persons with dementia (PWD) worldwide is expected to increase dramatically [2]. As a condition predominately of old age, PWD often have other comorbidities [3, 4]. A recent study found more chronic conditions and higher numbers of repeat medications prescribed to PWD than patients of the same age without dementia [5]. This is unsurprising, given that multiple chronic conditions often require management with multiple medicines [4]. Subsequently, medication regimens for these patients can become complex and difficult to manage. Currently, over two-thirds of PWD reside in the community sector and are commonly supported by informal carers, such as family members [6]. PWD frequently rely on carers to help with medicine-related activities, often referred to as 'medicines management', which has been defined as:

"Encompassing the entire way that medicines are selected, procured, delivered, prescribed, administered and reviewed to optimise the contribution that medicines make to producing informed and desired outcomes of patient care" [7].

The core components of this process are prescribing, dispensing, adherence and medication review. Medicines management for PWD has been described as a continuum, whereby patients can range in ability from being independent to completely dependent on carers [8]. It has been suggested that effective medicines management could significantly improve the provision of care for PWD [9]. Medicines management for older people is acknowledged as a challenge, and those suffering cognitive decline are more at risk of medication errors $[9,10]$. This can be due to reasons such as nonadherence, by missing doses of their prescribed medications or, in contrast, over-adherence by taking too much of these medicines. It may also result from the patient not recognising that a medication error has occurred, for example, during the dispensing process or an unintentional change in dose by the prescriber. Medicines "mismanagement" can result in a variety of problems ranging from inadequate symptom control to hospitalisation [11].

Medicines management for PWD is a practice and policy priority. In the United Kingdom (UK), the Department of Health issued a National Dementia Strategy in 2009, which placed emphasis on the appropriateness of antipsychotic medication in this patient population [12]. The limited research conducted to date on medicines use in PWD has focused heavily on antipsychotic prescribing [13, 14]. Trials have been conducted to evaluate interventions involving various stages in the process of medicines management in older people, such as improving adherence [15] and using medication reviews to achieve various outcomes including reducing hospital admissions, or improving the 
appropriateness of medication regimens [16-18]. However, although PWD may have participated, they have not been the focus of interest.

As previously noted, PWD are unique in their medicines management needs and hence, there is a need for trials to be conducted in this area. Therefore, the aim of this systematic review is to identify randomised controlled trials (RCTs) evaluating medicines management interventions for PWD living in the community or care home setting, and to assess the effectiveness of these interventions.

\section{Methods}

This systematic review was conducted, and is reported below, in accordance with the Preferred Reporting Items for Systematic Reviews and Meta-Analyses (PRISMA) [19].

\subsection{Eligibility criteria}

All RCTs, including cluster randomised trials (cRCTs) were eligible for inclusion. This review included participants of any age with dementia, living in the community or in a care home, with or without nursing care. Interventions aimed at participants who have a role in caring for PWD, such as carers (either formal or informal), or healthcare professionals were also eligible for inclusion. Interventions considered eligible for inclusion had to involve at least one component of medicines management, i.e. prescribing, dispensing, adherence and/or medication review [7]. Interventions incorporating more than one aspect of medicines management, or indeed those that focused on a specific area, for example prescribing, were included. All outcomes were considered. Non-English language articles were excluded.

\subsection{Identification of studies}

Six databases were searched in February 2016 from inception until the search date, including Ovid Medline, Embase, PsycINFO, CINAHL, Cochrane CENTRAL and Web of Science. Search terms were developed in consultation with a subject librarian, and are outlined in the search strategy in Online Resource 1. In addition, three trial registries (Research Registry, International Clinical Trials Registry Platform and ClinicalTrials.gov) were searched to identify any ongoing studies. Extensive hand searching of reference lists of eligible articles was also completed. Titles and abstracts of retrieved articles were initially screened for inclusion by one reviewer (MMcG). On removal of articles that did not meet the inclusion criteria, full-texts were obtained and independently screened by two reviewers ( $M M c G$ and $\mathrm{HEB}$ ). Where there was uncertainty or disagreement over inclusion of an article, this was resolved by consultation and discussion with a third reviewer (CMH).

\subsection{Data collection and analysis}


A data extraction form was developed and piloted to improve usability. Data extraction was completed independently by two reviewers (MMcG and CR). Details recorded included first author, year of publication, and country of origin. Detailed information on the interventions were extracted including description of the intervention, description of control and usual care groups, setting, provider, and duration of the intervention, and outcomes measured.

Given the broad scope of medicines management, it was anticipated a priori that a meta-analysis would not be feasible. Therefore, it was decided to present this review as a narrative analysis. The outcomes identified were grouped into different categories of related outcomes, derived from the Cochrane Effective Practice and Organisation of Care (EPOC) Group [20].

\subsection{Risk of bias}

An assessment of quality was completed for all the included studies, using the Cochrane tool for assessing the risk of bias [21]. Studies were assessed either to be at high, low or unclear risk of bias.

\section{Results}

A total of 1,358 articles were retrieved from initial database searches. In addition, three studies were identified from trial registries, and four articles from screening reference lists. On removal of duplicates and non-English language articles, 990 articles were screened for eligibility based on their titles and abstracts. This process resulted in 35 full-text articles to be screened by two reviewers (MMcG and HEB). Of these, 32 articles were excluded, leaving three articles eligible for inclusion in the review. An overview of screening and assessment of papers is presented in Figure 1.

[Insert Figure 1]

\subsection{Characteristics of studies}

As anticipated, the three included studies were heterogeneous in terms of intervention components and outcomes measured, and therefore this review is presented as a narrative summary of the design and effectiveness of the interventions. The three included studies were conducted in two countries (the UK $[22,23]$ and the United States of America (USA) [24]), and were published between 2006 and 2016. Two studies were cRCTs [22, 23] and one study was an unblinded RCT [24].

A total of 475 patients were included across the three studies. Two settings were involved, nursing homes $[22,23]$ and the community [24]. Length of follow-up ranged from two months to twelve months. Characteristics of the included studies are summarised in Table 1.

[Insert Table 1] 


\subsection{Characteristics of the interventions}

The three interventions targeted different components of medicines management. Two of the interventions, both of which were conducted in the care home setting, focused on medication review, which in turn influenced prescribing $[22,23]$. The third intervention was community-based and focused on adherence and administration issues [24]. None of the included studies involved the dispensing aspect of medicines management.

Intervention providers varied, with nurses being common to all three interventions, and the sole intervention provider in the study by Jordan et al. [23]. This intervention involved the administration of the West Wales Adverse Drug Reaction Profile for Mental Health Medicines to care home residents [23]. The Profile consists of a template seeking to identify adverse drug events specific to antipsychotic, antiepileptic and antidepressant medication [23]. It was developed for use by nurses, but facilitates discussions among multi-disciplinary teams, particularly in relation to medication review and prescribing [23]. The study by Fossey et al. was also conducted in the care home setting, and was delivered by either a psychologist, an occupational therapist, or a nurse, and consisted of a training package focusing on alternatives to medication to manage agitation, aimed at nursing home staff [22]. A comprehensive medication review focusing on reducing psychotropic drug use was conducted with residents of both intervention and control homes prior to implementation of the intervention [22]. Lingler et al. reported on a community-based intervention, which was provided by either a nurse or a social worker to carers of PWD [24]. This was a problem-solving intervention aimed at carers of PWD, in which the intervention provider discussed issues that carers were experiencing with regards to adherence and administration of medicines, allowing potential solutions to be discussed [24].

\subsection{Effect of interventions on outcomes}

\subsubsection{Medication-related outcomes}

The effects of the interventions on medication-related outcomes are summarised in Table 1.

\section{Medication management deficiencies}

Lingler et al. measured medication management deficiencies, using two tools, the Medication Management Instrument for Deficiencies in the Elderly (MedMaIDE), and the Medication Deficiency Checklist (MDC) [24]. The MedMaIDE tool broadly measures medicines management issues in the community setting [25]. Specifically, it addresses problems relating to patients' or carers' knowledge of medicines, proficiency in ordering medicines, and any administration issues [25]. The authors of this study overcame limitations of this tool by developing the MDC, which enables information regarding specific errors by carers to be recorded [24]. Overall, the intervention failed to demonstrate 
an effect, with no significant difference between control and intervention groups (Table 1) [24]. The most common issues observed at follow-up were dropping or losing pills, carers forgetting to administer doses, doses being administered at the wrong time and the patient forgetting to take a dose, all of which were observed in both groups [24]. The final most common deficiency was the wrong dose being taken from a compliance aid was observed only in the usual care group.

\section{Use of psychotropic drugs}

Two of the studies assessed the reduction in use of psychotropic medicines [22, 23]. Fossey et al. considered antipsychotic use and dosage as the primary outcome measure, and measured use of other psychotropic drugs as a secondary outcome. A statistically significant reduction in antipsychotic use was observed (Table 1) [22]. A reduction in dose of antipsychotic and a reduction in use of other psychotropic drugs was also observed, however these effects did not reach statistical significance (Table 1) [22]. Jordan et al. measured the effect on mental health medicines, which they defined as antipsychotics, antiepileptics and antidepressants, and a statistically significant reduction was observed (Table 1) [23].

\subsubsection{Patient related outcomes}

Dementia and illness severity and activities of daily living

Jordan et al. measured dementia severity, which was reported as behavioural and psychological symptoms (BPSD), and activities of daily living (ADL). Although ADL scores and BPSD deteriorated slightly, changes were not statistically significant [23].

\section{Agitation and aggression}

Fossey et al. [22] measured agitation and aggression, using the Cohen-Mansfield Agitation Inventory (CMAI), a rating scale which records the frequency at which certain behaviours indicating agitation are exhibited [26]. There were no significant differences in the levels of agitation in patients in intervention homes compared to the control homes [22]. Incidents of aggression, towards staff or other residents, were similar across intervention and control groups [22].

\section{Quality of life and wellbeing}

Quality of life (QOL) and wellbeing of residents was reported by Fossey et al. [22]. Ratings for wellbeing were reported to be similar across intervention and control groups [22]. Although QOL was specifically recorded as a secondary outcome, the authors reported time asleep and time withdrawn under this outcome [22]. The intervention was reported to only have had a small impact on residents appearing withdrawn, and no noticeable effect on residents spending time asleep [22]. 


\subsubsection{Adverse effects or harms}

Falls

Falls were considered by Fossey et al. and Jordan et al. [22, 23]. In Fossey et al. the number of residents having experienced at least one fall during a 12-month period was similar across intervention (52.0\%) and control homes (54.6\%) [22]. Jordan et al. also reported similar proportions of documented falls associated with Profile use (25\%) and without Profile use (28\%) [23].

\subsubsection{Resource use}

Costs associated with delivery of intervention

The costs associated with delivering the intervention was measured by Jordan et al [23]. The average costs of delivery of the West Wales Adverse Drug Reaction Profile ranged from $f 7$ to $f 41$ per patient, corresponding to administration times of between 10-60 minutes [23].

\section{$\underline{3.3 .5 \text { Satisfaction }}$}

Lingler et al. measured satisfaction of carers who received the intervention [24]. Overall, carers rated the intervention highly, with $88 \%$ reporting that the topics covered by the intervention were useful and relevant, and $92 \%$ finding the intervention valuable for managing the patient's treatment plan [24].

\subsection{Quality assessment}

The risk of bias summary is displayed in Figure 2, and shows the relative risk of bias of each of the three included studies. Two of the three studies were judged to be at low risk of bias $[22,23]$ with the third study judged as being of unclear risk of bias [24].

[Insert Figure 2]

\section{Discussion}

This systematic review highlights the limited research conducted on medicines management for PWD, with only three studies included. In particular, there is a paucity of interventions aimed at communitydwelling patients, with only one of the studies (Lingler et al.) including PWD living at home, despite the majority of PWD residing in the community $[6,24]$. This review found evidence to suggest that interventions incorporating medication review aimed at PWD can successfully reduce psychotropic drug prescribing $[22,23]$. Whilst previous reviews have identified interventions to reduce psychotropic drug use and manage BPSD [27-29], to the best of the authors' knowledge, this is the first systematic review to consider medicines management interventions holistically in this patient population. 
It is unsurprising that two of the three interventions included in this review focused on psychotropic drug use, given the well-established adverse effects of these drugs. Previous research has highlighted the negative consequences resulting from the use of antipsychotics in PWD, ranging from weight gain and extrapyramidal symptoms, to stroke and mortality [30, 31]. In most cases, the risks of long-term treatment are too great to be justified [30]. Many reviews have considered non-pharmacological options to be the most appropriate first-line treatment for BPSD, including psychological interventions and caregiver education [28, 32-34]. Indeed, much of the strongest evidence for improving BPSD, along with patient and carer quality of life, exists from non-pharmacological interventions [34, 35]. However, it must be acknowledged that in some circumstances, antipsychotics and other psychotropic drugs may be required, for example when the patient becomes a danger to themselves and others $[33,36]$. Therefore, it is important that the discontinuation of psychotropic drugs does not lead to inadequate symptom control, and consideration must be given to the clinical impact of interventions which result in reduced psychoactive drug use.

It was promising that the reduction in psychotropic drug use observed by both Fossey et al. and Jordan et al. did not result in an increase in BPSD $[22,23]$. Furthermore, this effect was sustained postintervention, however follow-up periods varied between five months (Jordan et al.) and 12 months (Fossey et al.). Although demonstrating positive effects on medicine-related outcomes, the interventions failed to show beneficial effects on other outcomes of interest, for example, well-being or $\operatorname{ADL}[22,23]$. This is consistent with previous research on medication review interventions in other populations which have also reported improvements in medicines-related outcomes, such as the number of medicines prescribed and medication appropriateness, but no effect on outcomes such as mortality or hospitalisations [17, 37, 38]. Additionally, neither intervention reduced the number of falls $[22,23]$. These findings echo a previous study reporting an intervention aimed at reducing inappropriate psychotropic drug use in older people living in nursing homes, which similarly demonstrated no effect on falls despite a reduction in psychotropic drugs [39]. Conversely, a small study evaluating the effect of a pharmaceutical intervention encompassing medication review on hospital in-patients reported a $47 \%$ reduction in falls post-intervention following a decrease in several medication classes, including psychotropic drugs, sedatives, cardiovascular drugs and analgesics [40]. This evidence indicates that reducing psychotropics alone may not be sufficient in reducing falls, but that a full review of a patient's medication regimen can identify other medicines that could increase the risk of falls. Aside from falls, potentially inappropriate medication has many consequences, particularly in PWD who due to increasing age and presence of co-morbidities, are already vulnerable to adverse effects of medication [4, 41]. Research has highlighted that almost two-thirds of community-dwelling PWD receive potentially inappropriate medication, and therefore it is prudent 
that future interventions seek to identify the most appropriate methods of conducting a comprehensive medication review for these patients [41].

Once a successful medicines review has been undertaken, and the medication regimen has been optimised, the next step in the medicines management continuum is supporting the patient to adhere to this regimen. Whilst interventions have been conducted to improve adherence in older people, they frequently exclude patients with cognitive impairment, despite memory problems being indicated as a predictor of poor adherence $[11,42,43]$. Only one study in this review, conducted by Lingler et al., considered adherence and did not demonstrate effectiveness, with adherence issues the most common medicines management deficiencies identified two months post-intervention [24]. The follow-up period of this study was the shortest of the three included interventions, and so long-term impact cannot be evaluated. However, this intervention adds to the evidence that carers of PWD often struggle with medicines management activities $[6,24]$. Indeed, it was more commonly reported that carers forgot to administer medication doses than patients forgetting to take their medication [24]. Therefore, it is also important that future interventions aim to find the most effective strategies to support carers with this process. A recent Cochrane review assessing adherence interventions in the general population demonstrated limited effectiveness of these interventions to date [15]. This review recommended that future interventions are well-designed, feasible, and seek to achieve a long-term effect, not only in terms of adherence, but also clinical outcomes [15].

In 2008, the Medical Research Council (MRC) issued guidance advocating the incorporation of theory into developing interventions [44]. Two of the included interventions were published after this guidance $[23,24]$, but only one of these studies reported that theory had guided the design of their intervention [24]. This study reported using social cognitive theory and self-efficacy theory as the theoretical frameworks that formed the basis of their problem-solving intervention [24]. Although this intervention did not demonstrate any significant difference in medicines management deficiencies, this is not to say that theory-based interventions are ineffective [24]. Of note, this study provided little detail on the design of the intervention, other than stating the theories incorporated in its development [24]. This is a recognised problem, with many authors who cite theory as guiding their intervention failing to describe how this was achieved [45]. However, there is evidence that theorybased interventions are effective in assisting behaviour change, provided theory is used appropriately $[45,46]$.

The review considered only RCTs, as they yield the highest quality evidence [47], and indeed, two of the included studies were judged to be of low risk of bias $[22,23]$. However, the range of different outcomes reported across this small number of interventions made comparison of their effectiveness 
unfeasible. This issue is recognised in the literature, with the development of 'Core Outcome Sets' (COSs) increasingly advocated. A COS is a specific set of outcomes applicable to all trials in a particular clinical area or disease state [48]. A COS for medicines management interventions for PWD would prove invaluable to future research in this area, and assist assessment of the effectiveness of interventions.

Strengths of this review include the extensive searching completed across six databases, three trial registries, further hand-searching of reference lists, and compliance with best practice in terms of abstract screening and data extraction. However, there were several limitations. Studies may have been missed due to the search terms used comprising of 'medicines management' and derivatives of this term, rather than searching the constituent parts of this e.g. prescribing. However, we were interested in a more holistic approach to medicines management rather than just one component. Another limitation was that only articles published in the English language were included.

Overall, this systematic review highlights the lack of well-designed RCTs conducted in assessing medicines management interventions for PWD. The small number of interventions, together with the heterogeneity of intervention components and outcomes measured made it difficult to compare the effectiveness of the interventions. However, there is some evidence that medication review can be beneficial in terms of psychotropic drug prescribing $[22,23]$. Future research should aim to extend medication review to assess the appropriateness of medication beyond psychotropic drugs. Furthermore, with the rise in community-dwelling PWD, it is imperative that future interventions take a multidisciplinary approach, involving pharmacists, general practitioners (GPs), nurses and other members of the primary healthcare team, and aim to promote training and support for carers who may be struggling with the burden of medicines management for PWD [6].

\section{Conclusion}

This systematic review examined the effectiveness of medicines management interventions for PWD. A reduction in psychotropic drug use was a key finding of the two studies incorporating medication review in care homes. The community-based study failed to show a significant difference in its primary outcome, medication management deficiencies. Overall, there is limited work to date in this area, with an urgent need for well-designed interventions aiming to improve medicines management as a whole. 


\section{Acknowledgements}

The authors would like to thank Mr. Patrick Elliott (Queen's University Belfast Library) for his assistance with developing the search strategy.

\section{Compliance with Ethical Standards}

\section{Conflicts of interest}

Mairead McGrattan, Cristín Ryan, Heather E. Barry and Carmel M. Hughes have no conflicts of interest to declare.

\section{Funding}

MMcG is supported by a PhD Research Studentship from the Department for Employment and Learning in Northern Ireland. HEB is supported by funding from the Research \& Development Division of the Public Health Agency in Northern Ireland and The Atlantic Philanthropies (COM/5010/14). The funders played no role in the design, analysis or conduct of the review. 


\section{References}

[1] World Health Organization. Dementia: A Public Health Priority. 2012. Available from: http://www.who.int/mental health/publications/dementia report 2012/en/ [Accessed 7/08/2017].

[2] Prince M, Bryce R, Albanese E, Wimo A, Ribeiro W, Ferri CP. The global prevalence of dementia: a systematic review and metaanalysis. Alzheimers Dement 2013; 9: 63-75.

[3] Salisbury C, Johnson L, Purdy S, Valderas JM, Montgomery AA. Epidemiology and impact of multimorbidity in primary care: a retrospective cohort study. Br J Gen Pract 2011; 61: e12e21.

[4] Schubert CC, Boustani M, Callahan CM, et al. Comorbidity profile of dementia patients in primary care: Are they sicker? J Am Geriatr Soc 2006; 54: 104-109.

[5] Clague F, Mercer SW, McLean G, Reynish E, Guthrie B. Comorbidity and polypharmacy in people with dementia: insights from a large, population-based cross-sectional analysis of primary care data. Age Ageing 2017; 46: 33-39.

[6] Smith F, Grijseels MS, Ryan P, Tobiansky R. Assisting people with dementia with their medicines: experiences of family carers. Int J Pharm Pract 2015; 23: 44-51.

[7] Audit Commission. (2001). A spoonful of sugar-medicines management in NHS hospitals. Audit Commission: London. Available from:

http://webarchive.nationalarchives.gov.uk/20150423154441/http://archive.auditcommission.gov.uk/auditcommission/aboutus/publications/pages/national-reports-andstudies-archive.aspx.html [Accessed 7/08/2017].

[8] Elliott R, Goeman D, Beanland C, Koch S. Ability of older people with dementia or cognitive impairment to manage medicine regimens: a narrative review. Curr Clin Pharmacol 2015; 10: 213-221.

[9] Rogers S, Martin G, Rai G. Medicines management support to older people: Understanding the context of systems failure. BMJ Open 2014; 7: e005302. doi: 10.1136/bmjopen-2014005302.

[10] Field TS, Mazor KM, Briesacher B, Debellis KR, Gurwitz JH. Adverse drug events resulting from patient errors in older adults. J Am Geriatr Soc 2007; 55: 271-276.

[11] Arlt S, Lindner R, Rösler A, von Renteln-Kruse W. Adherence to medication in patients with dementia. Drugs Aging 2008; 25: 1033-1047.

[12] Department of Health. Living well with dementia: A National Dementia Strategy. 2009. Available from https://www.gov.uk/ [Accessed 7/08/2017]. 
[13] Ballard C, Hanney ML, Theodoulou M, et al. The dementia antipsychotic withdrawal trial (DART-AD): long-term follow-up of a randomised placebo-controlled trial. Lancet Neurol 2009; 8: 151-157.

[14] Guthrie B, Clark SA, McCowan C. The burden of antipsychotic drug prescribing in people with dementia: a population database study. Age Ageing 2010; 39: 637-642.

[15] Nieuwlaat R, Wilczynski N, Navarro T, et al. Interventions for enhancing medication adherence. Cochrane Database of Syst Rev 2014; 11: CD000011. doi:10.1002/14651858.CD000011.pub4.

[16] Zermansky AG, Petty DR, Raynor DK, Freemantle N, Vail A, Lowe CJ. Randomised controlled trial of clinical medication review by a pharmacist of elderly patients receiving repeat prescriptions in general practice. BMJ 2001; 323: 1340-1343.

[17] Holland R, Lenaghan E, Harvey I, et al. Does home based medication review keep older people out of hospital? The HOMER randomised controlled trial. BMJ 2005; 330: 293.

[18] RESPECT trial team. Effectiveness of shared pharmaceutical care for older patients: RESPECT trial findings. J Gen Pract 2010; 60: e10-9. doi: 10.3399/bjgp09X473295.

[19] Moher D, Liberati A, Tetzlaff J, Altman DG. Preferred reporting items for systematic reviews and meta-analyses: the PRISMA statement. Ann Intern Med 2009; 151: 264-269.

[20] Effective Practice and Organisation of Care (EPOC). What outcomes should be reported in EPOC reviews? EPOC Resources for review authors. Oslo: Norwegian Knowledge Centre for the Health Services. 2013. Available from: http://epoc.cochrane.org [Accessed 7/08/2017].

[21] The Cochrane Collaboration. Cochrane handbook for systematic reviews of interventions, Version 5.1.0, 2011. Available from http://handbook.cochrane.org/ [Accessed 7/08/2017].

[22] Fossey J, Ballard C, Juszczak I, Alder N, Jacoby R, Howard R. Effect of enhanced psychosocial care on antipsychotic use in nursing home residents with severe dementia: cluster randomised trial. BMJ 2006; 332: 756-761.

[23] Jordan S, Gabe-Walters ME, Watkins A, et al. Nurse-led medicines' monitoring for patients with dementia in care homes: a pragmatic cohort stepped wedge cluster randomised trial. PloS One 2015. 10: e0140203. doi: 10.1371/journal.pone.0140203.

[24] Lingler JH, Sereika SM, Amspaugh CM, et al. An intervention to maximize medication management by caregivers of persons with memory loss: Intervention overview and twomonth outcomes. Geriatr Nurs 2016; 37: 186-191.

[25] Orwig D, Brandt N and Gruber-Baldini. Medication management assessment for older adults in the community. Gerontologist 2006; 46: 661-668. 
[26] Cohen-Mansfield J. Agitated behaviors in the elderly. II. Preliminary results in the cognitively deteriorated. J Am Geriatr Soc 1986; 34: 722-727.

[27] Thompson Coon J, Abbott R, Rogers M et al. Interventions to reduce inappropriate prescribing of antipsychotic medications in people with dementia resident in care homes: a systematic review. JAMDA 2014; 15: 706-718.

[28] Testad I, Corbett A, Aarsland D et al. The value of personalized psychosocial interventions to address behavioural and psychological symptoms in people with dementia living in care home settings: a systematic review. Int Psychogeriatri 2014; 26: 1083-1098.

[29] Richter T, Meyer G, Möhler R, Köpke S. Psychosocial interventions for reducing antipsychotic medication in care home residents. Cochrane Database of Syst Rev 2012; 12: CD008634. doi: 10.1002/14651858.CD008634.pub2.

[30] Gareri P, De Fazio P, Manfredi VGL, De Sarro G. Use and safety of antipsychotics in behavioral disorders in elderly people with dementia. J Clin Psychopharmacol 2014; 34: 109123.

[31] Kales HC, Gitlin LN, Lyketsos CG. Assessment and management of behavioral and psychological symptoms of dementia. BMJ 2015; 350: h369. doi: 10.1136/bmj.h369.

[32] Ballard CG, Gauthier S, Cummings JL et al. Management of agitation and aggression associated with Alzheimer disease. Nat Rev Neurol 2009; 5: 245-255.

[33] Gauthier S, Cummings J, Ballard C et al. Management of behavioral problems in Alzheimer's disease. Int Psychogeriatr 2010; 22: 346-372.

[34] Gitlin LN, Kales HC, Lyketsos CG. Nonpharmacologic management of behavioral symptoms in dementia. JAMA 2012; 308: 2020-2029.

[35] Kales HC, Gitlin LN, Lyketsos CG. Management of neuropsychiatric symptoms of dementia in clinical settings: recommendations from a multidisciplinary expert panel. J Am Geriatri Soc 2014; 62: 762-769.

[36] Greenblatt KH, Greenblatt DJ. Use of antipsychotics for the treatment of behavioral symptoms of dementia. J Clin Pharmacol 2016; 56: 1048-1057.

[37] Wallerstedt SM, Kindblom JM, Nylén K, Samuelsson O, Strandell A. Medication reviews for nursing home residents to reduce mortality and hospitalization: systematic review and meta-analysis. Br J Clin Pharmacol 2014; 78: 488-497.

[38] Alldred DP, Kennedy MC, Hughes C, Chen TF, Miller P. Interventions to optimise prescribing for older people in care homes. Cochrane Database of Syst Rev 2016; 2: CD009095. doi:10.1002/14651858.CD009095.pub3. 
[39] Patterson SM, Hughes CM, Crealey G et al. An evaluation of an adapted U.S. model of pharmaceutical care to improve psychoactive prescribing for nursing home residents in Northern Ireland (Fleetwood Northern Ireland Study). J Am Geriatri Soc 2010; 58: 44-53.

[40] Haumschild MJ, Karfonta TL, Haumschild MS, Phillips SE. Clinical and economic outcomes of a fall-focused pharmaceutical intervention program. Am J Health-Syst Pharm 2003; 60: 102932.

[41] Barry HE, Cooper JA, Ryan C, et al. Potentially inappropriate prescribing among people with dementia in primary care: a retrospective cross-sectional study using the enhanced prescribing database. J Alzheimers Dis 2016; 52: 1503-1513.

[42] Johnson G, Elliott RA, Stewart DC. A systematic review of intervention to improve medication taking in elderly patients prescribed multiple medications. Drugs Aging 2008; 25: 307-324.

[43] Gellad WF, Grenard JL, Marcum ZA. A systematic review of barriers to medication adherence in the elderly: looking beyond cost and regimen complexity. Am J Geriatr Pharmacother 2011; 9: 11-23.

[44] Craig P, Dieppe P, Macintyre S, et al. Developing and evaluating complex interventions: the new Medical Research Council guidance. BMJ 2008; 337: 979-983.

[45] Michie S, Prestwich A. Are interventions theory-based? Development of a theory coding scheme. Health Psychol 2010; 29: 1-8.

[46] Nathan N, Yoong SL, Sutherland R, et al. Effectiveness of a multicomponent intervention to enhance implementation of a healthy canteen policy in Australian primary schools: a randomised controlled trial. Int J Behav Nutr Phy 2016; 13: 106.

[47] Huwiler-Müntener K, Jüni $P$, Junker $C$, Egger M. Quality of reporting of randomized trials as a measure of methodologic quality. JAMA. 2002; 287: 2801-2804.

[48] Williamson PR, Altman DG, Blazeby JM, et al. Developing core outcome sets for clinical trials: issues to consider. Trials 2012; 13: 1-8. 
Legends

Figure 1 PRISMA flow diagram of screening process and reasons for exclusion of studies

Table 1 Characteristics of included studies and effect of interventions on medication-related outcomes

Figure 2 Risk of bias summary for the three included studies [21]

\section{Electronic supplementary information}

Additional supplementary material may be found in the online version of this article:

Online Resource 1: MEDLINE Search strategy

Online Resource 2: PRISMA Checklist 
Table 1: Characteristics of included studies and effect of interventions on medication-related outcomes

\begin{tabular}{|c|c|c|c|c|c|c|c|c|}
\hline $\begin{array}{l}\text { Author } \\
\text { (country) }\end{array}$ & Study type & $\begin{array}{l}\text { Total } \\
\text { number of } \\
\text { participants } \\
\text { recruited }\end{array}$ & $\begin{array}{l}\text { Participant } \\
\text { characteristics } \\
\text { 1. Mean age } \\
\text { 2. \% male } \\
\text { 3. Mean number of } \\
\text { medication ( } \pm S D \text { ) }\end{array}$ & $\begin{array}{l}\text { Intervention } \\
\text { provider }\end{array}$ & $\begin{array}{l}\text { Description of } \\
\text { intervention }\end{array}$ & $\begin{array}{l}\text { Component of } \\
\text { medicines } \\
\text { management } \\
\text { targeted }\end{array}$ & $\begin{array}{l}\text { Follow-up } \\
\text { period }\end{array}$ & $\begin{array}{l}\text { Medication- } \\
\text { related } \\
\text { outcomes } \\
\text { measured }\end{array}$ \\
\hline $\begin{array}{l}\text { Fossey et } \\
\text { al. } \\
\text { (United } \\
\text { Kingdom) }\end{array}$ & $\begin{array}{l}\text { Cluster } \\
\text { RCT }\end{array}$ & $N=349$ & $\begin{array}{l}\text { 1. NR for total sample. } \\
\text { Intervention median: } \\
82 \text { SD NR; control } \\
\text { median: } 82 \text { SD NR } \\
\text { 2. NR for total sample. } \\
\text { Intervention 65\%; } \\
\text { control } 61 \% \\
\text { 3. NR }\end{array}$ & $\begin{array}{l}\text { Nurses, } \\
\text { psychologist or } \\
\text { occupational } \\
\text { therapist }\end{array}$ & $\begin{array}{l}\text { Training and } \\
\text { support } \\
\text { intervention } \\
\text { delivered to } \\
\text { nursing home } \\
\text { staff in } \\
\text { intervention } \\
\text { homes. } \\
\text { Medication } \\
\text { review delivered } \\
\text { by consultant old } \\
\text { age psychiatrist } \\
\text { to both control } \\
\text { group and } \\
\text { intervention } \\
\text { group. }\end{array}$ & $\begin{array}{l}\text { Medication } \\
\text { review }\end{array}$ & 12 months & $\begin{array}{l}\text { Neuroleptic use } \\
\text { Effect shown } \\
\text { (statistically } \\
\text { significant) } \\
\text { Greater } \\
\text { reduction in } \\
\text { neuroleptic use } \\
\text { in intervention } \\
\text { homes than } \\
\text { control homes } \\
\text { (mean } \\
\text { difference } \\
\text { 19.1\% 95\% Cl } \\
\text { 0.5-37.7\%; } \\
\text { p=0.045) } \\
\text { Dose of } \\
\text { neuroleptic } \\
\text { Effect shown } \\
\text { (not statistically } \\
\text { significant) } \\
\text { Mean dose of } \\
\text { neuroleptic } \\
\text { lower in } \\
\text { intervention }\end{array}$ \\
\hline
\end{tabular}




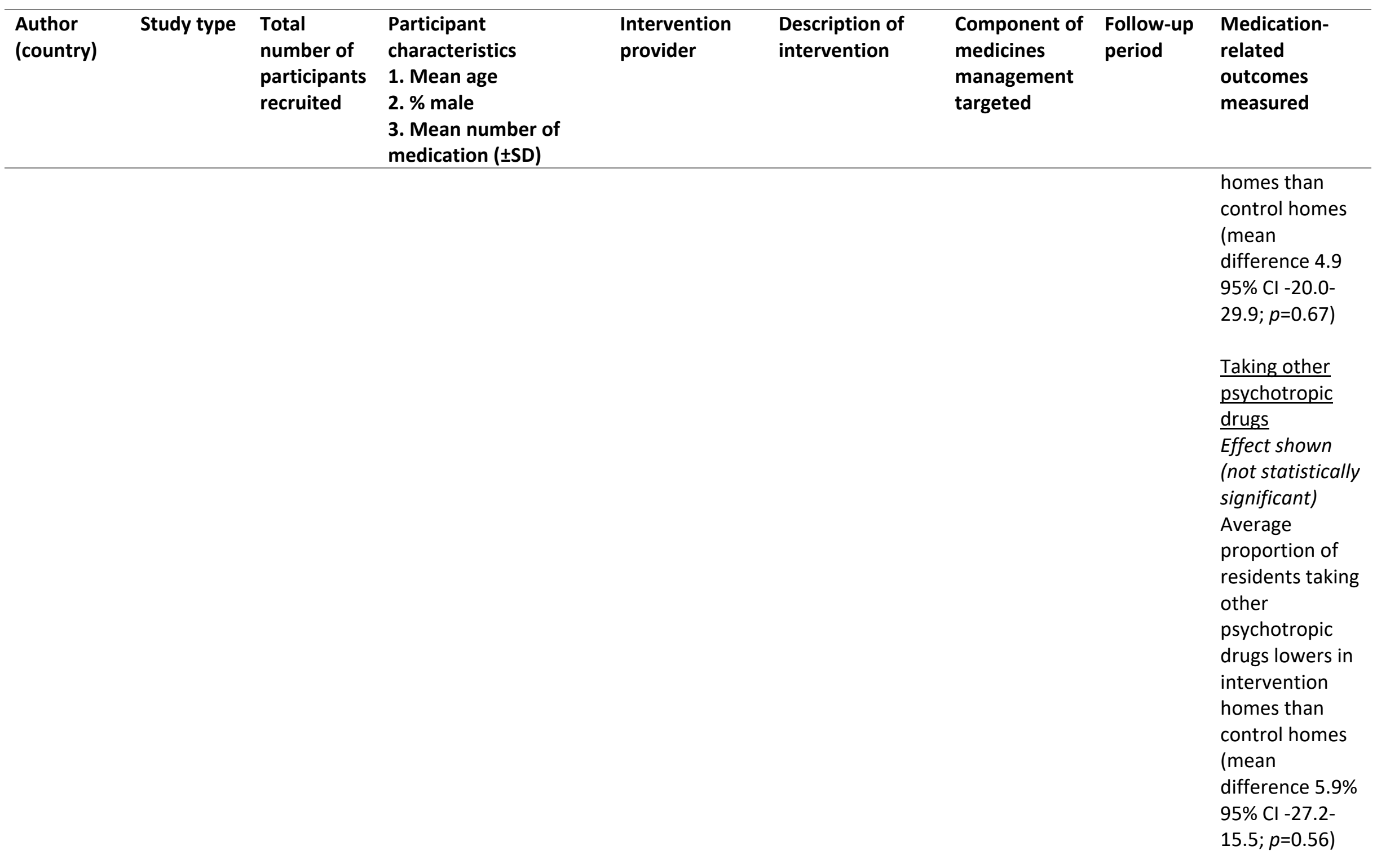




\begin{tabular}{|c|c|c|c|c|c|c|c|c|}
\hline $\begin{array}{l}\text { Author } \\
\text { (country) }\end{array}$ & Study type & $\begin{array}{l}\text { Total } \\
\text { number of } \\
\text { participants } \\
\text { recruited }\end{array}$ & $\begin{array}{l}\text { Participant } \\
\text { characteristics } \\
\text { 1. Mean age } \\
\text { 2. \% male } \\
\text { 3. Mean number of } \\
\text { medication ( } \pm S D)\end{array}$ & $\begin{array}{l}\text { Intervention } \\
\text { provider }\end{array}$ & $\begin{array}{l}\text { Description of } \\
\text { intervention }\end{array}$ & $\begin{array}{l}\text { Component of } \\
\text { medicines } \\
\text { management } \\
\text { targeted }\end{array}$ & $\begin{array}{l}\text { Follow-up } \\
\text { period }\end{array}$ & $\begin{array}{l}\text { Medication- } \\
\text { related } \\
\text { outcomes } \\
\text { measured }\end{array}$ \\
\hline $\begin{array}{l}\text { Jordan et } \\
\text { al. } \\
\text { (United } \\
\text { Kingdom) }\end{array}$ & $\begin{array}{l}\text { Cluster } \\
\text { RCT }\end{array}$ & $N=43$ & $\begin{array}{l}\text { 1. } 78.7 \pm 11.00 \\
\text { 2. } 41.9 \% \text { male } \\
\text { 3. } 9.3 \pm 3.7\end{array}$ & Nurses & $\begin{array}{l}\text { Administration of } \\
\text { West Wales } \\
\text { Adverse Drug } \\
\text { Reaction Profile } \\
\text { for mental health } \\
\text { medicines }\end{array}$ & $\begin{array}{l}\text { Medication } \\
\text { review }\end{array}$ & $\begin{array}{l}\text { Five } \\
\text { months }\end{array}$ & $\begin{array}{l}\frac{\text { Medication- }}{\text { related }} \\
\frac{\text { problems }}{\text { Effect shown }} \\
\text { (statistically } \\
\text { significant) } \\
\text { More problems } \\
\text { found and } \\
\text { addressed with } \\
\text { profile use than } \\
\text { without } \\
\text { [Total problems } \\
\text { found 15.81 } \\
\text { with profile, } \\
7.30 \\
\text { without } \\
\text { ( } p<0.001 \text { )] } \\
\text { [Total problems } \\
\text { addressed } 9.86 \\
\text { with profile, } \\
6.02 \text { without } \\
\text { ( } p<0.001 \text { )] }\end{array}$ \\
\hline & & & & & & & & $\begin{array}{l}\text { Mental health } \\
\text { medicines }\end{array}$ \\
\hline
\end{tabular}




\begin{tabular}{|c|c|c|c|c|c|c|c|c|}
\hline $\begin{array}{l}\text { Author } \\
\text { (country) }\end{array}$ & Study type & $\begin{array}{l}\text { Total } \\
\text { number of } \\
\text { participants } \\
\text { recruited }\end{array}$ & $\begin{array}{l}\text { Participant } \\
\text { characteristics } \\
\text { 1. Mean age } \\
\text { 2. \% male } \\
\text { 3. Mean number of } \\
\text { medication ( } \pm S D)\end{array}$ & $\begin{array}{l}\text { Intervention } \\
\text { provider }\end{array}$ & $\begin{array}{l}\text { Description of } \\
\text { intervention }\end{array}$ & $\begin{array}{l}\text { Component of } \\
\text { medicines } \\
\text { management } \\
\text { targeted }\end{array}$ & $\begin{array}{l}\text { Follow-up } \\
\text { period }\end{array}$ & $\begin{array}{l}\text { Medication- } \\
\text { related } \\
\text { outcomes } \\
\text { measured }\end{array}$ \\
\hline & & & & & & & & $\begin{array}{l}\text { Effect shown } \\
\text { (statistically } \\
\text { significant) } \\
\text { Greater } \\
\text { reduction in } \\
\text { mental health } \\
\text { medicines } \\
\text { associated with } \\
\text { profile use } \\
\text { (12.1\%) than } \\
\text { without (3.6\%) } \\
\text { [aOR=4.45 } \\
(p=0.03)]\end{array}$ \\
\hline $\begin{array}{l}\text { Lingler et } \\
\text { al. } \\
\text { (United } \\
\text { States) }\end{array}$ & $\begin{array}{l}\text { Unblinded } \\
\text { RCT }\end{array}$ & $\begin{array}{l}N=83 \\
\text { patient- } \\
\text { carer dyads }\end{array}$ & $\begin{array}{l}\text { 1. NR for total sample. } \\
\text { Intervention mean } \\
\text { (patients): } 79.67 \pm 9.19 ; \\
\text { (caregivers): } 66.00 \pm \\
\text { 12.8; usual care mean } \\
\text { (patients): } 80.15 \pm 8.48 ; \\
\text { (caregivers): } 67.8 \pm 11.2 \\
\text { 2. NR for total sample. } \\
\text { Intervention (patients): } \\
33 \% ; \text { (caregivers): } 31 \% \text {; } \\
\text { usual care (patients): } \\
46 \% ; \text { (caregivers): } 29 \%\end{array}$ & $\begin{array}{l}\text { Nurses or } \\
\text { social workers }\end{array}$ & $\begin{array}{l}\text { One-to-one } \\
\text { discussion } \\
\text { between } \\
\text { intervention } \\
\text { provider and } \\
\text { caregiver in order } \\
\text { to address } \\
\text { medication- } \\
\text { related issues }\end{array}$ & $\begin{array}{l}\text { Adherence } \\
\text { and } \\
\text { administration }\end{array}$ & $\begin{array}{l}\text { Two } \\
\text { months }\end{array}$ & $\begin{array}{l}\frac{\text { Medication }}{\text { management }} \\
\text { deficiencies } \\
\text { No effect } \\
\text { shown } \\
\text { Both groups } \\
\text { had reduction } \\
\text { in medication } \\
\text { management } \\
\text { deficiencies but } \\
\text { no significant } \\
\text { difference } \\
\text { between }\end{array}$ \\
\hline
\end{tabular}




\begin{tabular}{|c|c|c|c|c|c|c|c|c|}
\hline $\begin{array}{l}\text { Author } \\
\text { (country) }\end{array}$ & Study type & $\begin{array}{l}\text { Total } \\
\text { number of } \\
\text { participants } \\
\text { recruited }\end{array}$ & $\begin{array}{l}\text { Participant } \\
\text { characteristics } \\
\text { 1. Mean age } \\
\text { 2. \% male } \\
\text { 3. Mean number of } \\
\text { medication }( \pm S D)\end{array}$ & $\begin{array}{l}\text { Intervention } \\
\text { provider }\end{array}$ & $\begin{array}{l}\text { Description of } \\
\text { intervention }\end{array}$ & $\begin{array}{l}\text { Component of } \\
\text { medicines } \\
\text { management } \\
\text { targeted }\end{array}$ & $\begin{array}{l}\text { Follow-up } \\
\text { period }\end{array}$ & $\begin{array}{l}\text { Medication- } \\
\text { related } \\
\text { outcomes } \\
\text { measured }\end{array}$ \\
\hline & & & $\begin{array}{l}\text { 3. NR for total sample. } \\
\text { Intervention: } 10.78 \pm \\
5.52 ; \text { usual care } 10.61 \pm \\
5.89\end{array}$ & & & & & $\begin{array}{l}\text { groups } \\
\text { (MedMaIDE } \\
{[\mathrm{F}=6.907 ; p} \\
<0.1] ; \mathrm{MDC} \\
{[\mathrm{F}=9.72 ; p} \\
<0.1] \text { ) }\end{array}$ \\
\hline & & & & & & & & $\begin{array}{l}\text { Most common } \\
\text { deficiencies } \\
\text { observed at } \\
\text { follow-up: } \\
\text { 1. Dropping/ } \\
\text { losing pills } \\
\text { 2. Carers } \\
\text { forgetting to } \\
\text { administer } \\
\text { doses } \\
\text { 3. Doses being } \\
\text { administered at } \\
\text { the wrong time } \\
\text { 4. Patient } \\
\text { forgetting to } \\
\text { take dose } \\
\text { 5. Wrong dose } \\
\text { taken from } \\
\text { compliance aid } \\
\text { (only observed }\end{array}$ \\
\hline
\end{tabular}




\begin{tabular}{|c|c|c|c|c|c|c|c|c|}
\hline $\begin{array}{l}\text { Author } \\
\text { (country) }\end{array}$ & Study type & $\begin{array}{l}\text { Total } \\
\text { number of } \\
\text { participants } \\
\text { recruited }\end{array}$ & $\begin{array}{l}\text { Participant } \\
\text { characteristics } \\
\text { 1. Mean age } \\
\text { 2. \% male } \\
\text { 3. Mean number of } \\
\text { medication ( } \pm S D)\end{array}$ & $\begin{array}{l}\text { Intervention } \\
\text { provider }\end{array}$ & $\begin{array}{l}\text { Description of } \\
\text { intervention }\end{array}$ & $\begin{array}{l}\text { Component of } \\
\text { medicines } \\
\text { management } \\
\text { targeted }\end{array}$ & $\begin{array}{l}\text { Follow-up } \\
\text { period }\end{array}$ & $\begin{array}{l}\text { Medication- } \\
\text { related } \\
\text { outcomes } \\
\text { measured }\end{array}$ \\
\hline
\end{tabular}

NR Not reported

SD Standard deviation

RCT Randomised controlled trial

$\mathrm{Cl}$ Confidence interval

aOR Adjusted odds ratio

MedMaIDE Medication Management Instrument for Deficiencies in the Elderly

MDC Medication deficiency checklist 
